\title{
Autoassociative Memory Evolving System Based on Fuzzy Basis Functions
}

\author{
Yevgeniy Bodyanskiy, Kharkiv National University of Radio Electronics, \\ Nataliya Teslenko, Kharkiv National University of Radio Electronics
}

\begin{abstract}
This paper proposes a neuro-fuzzy architecture of evolving autoassociative memory network. Learning of a given construction is based on fuzzy basis functions. The algorithm of membership functions centres determination is described and processes of fundamental memory patterns accumulation and their retrieval are considered. This hybrid neuro-fuzzy system combines advantages of artificial neural networks, fuzzy inference systems and evolving systems and its using allows researchers to increase autoassociative memory capacity without considerable complication of its construction.
\end{abstract}

Keywords - fundamental memory, evolving systems, autoassociative memory, neurons at data points, fuzzy basis functions

\section{INTRODUCTION}

One of the important properties of the biological brain is the ability to remember the information and later retrieve it using the system of associations. This means that once seen pattern can be identified even after a long time, in spite of the changes that might have taken place. Sufficiently wide class of artificial neural networks, called associative memory neural networks, simulates this function of brain [1-7].

An artificial memory usually represents either feedforward neural network (static associative memory), or recurrent (dynamic associative memory) neural network. Such a memory stores the patterns, which were presented to it (recording phase), and in retrieval phase recalls them from the memory, associating newly presented data with earlier seen. At the same time, all presented and recorded patterns form the set of fundamental memory.

In contrast to usual computer memory blocks in neural network memory information is allocated to the whole set of neurons, which form the network that raise the reliability of storing. Information search is executed not by address, but by content. The possibility of distorted or incomplete information processing is ensured that allows one to recognise correctly the whole pattern by its "noisy" fragment.

The main difference between neural network memory and approximating neural networks is that the latter realize unique nonlinear mapping

$$
y(k)=F(x(k)), y(k) \in R^{m}, x(k) \in R^{n},
$$

whereas associative memory maps to $y(k)$ all possible input vectors $x$ that belong to some neighbourhood of $x(k)$, such that $\|x-x(k)\|<\varepsilon$. Here $y(k), x(k)-(m \times 1),(n \times 1)$ are fundamental memory vectors recorded, $k=1,2, \ldots, l-$ the number of particular pattern in the set of fundamental memory, $\varepsilon$ - positive parameter.

Autoassociative memories that realize the mapping $x(k)=F(x(k))$ for all $x$ that belong to the neighbourhood defined by parameter $\varepsilon$ are widely spread among variety of neural networks memories structures. The main function of these neural networks is retrieval of incomplete or distorted information, e.g., pattern recognition by photo scrap or diagnostics using the data with gaps and mistakes.

Correlation matrix-memory, eigenvector automata, Hopfield neural network, autoassociative multilayer perceptron, bidirectional associative memory, "Brain-State-ina-Box" neural network model, are the most popular among neural networks memories [6]. The common disadvantage of given memories is their small capacity, which is defined by the ratio of recording patterns number $l$ to their dimensionality $n$. The value $l / n$ for these memories usually doesn't exceed unity.

Lattice-Based Associative Memory Networks (LAMN) [8,9] have a considerably larger capacity in comparison with the above-listed constructions. LAMN are very similar to widespread Radial Basis Functions Networks (RBFN) by architecture. Output signal of these networks is formed using linear combinations of mutually overlapping radial-basis bellshaped functions that are evenly distributed in $n$-dimensional input space.

The main difference between LAMN and RBFN is that multi-dimensional radial-basis functions are formed from the univariate fuzzy basis functions [10]. The centres of these functions are disposed equidistantly from each other on univariate axis that corresponds to $i$-th $(i=1,2, \ldots, n)$ component of multidimensional input signal. The curse of dimensionality that leads to exponential growth of hidden layer neurons with growth of input space dimensionality is the principal disadvantage of these neural networks.

Hybrid neuro-fuzzy systems [11,12] that combine the advantages of artificial neural networks and fuzzy inference system, provide the associative memories capacity increase without essential complication of construction.

\section{AUTOASSOCIATIVE MEMORY LEARNING BASED ON FUZZY BASIS FUNCTIONS}

The neuro-fuzzy architecture shown in Fig.1, is aimed for storing the fundamental memory patterns set $x^{*}(k)$, $k=1,2, \ldots, l, x^{*}(k) \in R^{n}$, which form $(n \times l)$-matrix $X^{*}$. The given architecture contains four layers of information 
processing and is sufficiently close to L.Wang-J.Mendel fuzzy network [10,13], although solves other problems.

The first layer is formed by $n l$ nodes, each of which realizes the membership function $\mu_{\tilde{x}_{i}^{*}(k)}$ that corresponds to the $i$-th coordinate of $k$-th stored pattern. These functions are defined on the interval $[0,1]$ that requires prior initial data encoding using the relationship

$$
\tilde{x}_{i}^{*}=\frac{x_{i}^{*}-x_{i}^{*^{* m i n}}}{x_{i}^{* \text { max }}-x_{i}^{*_{\text {min }}}},
$$

where $x_{i}^{* \max }$ and $x_{i}^{* \min }$ maximum and minimum elements of the $i$-th raw of matrix $X^{*}$ correspondingly. Inverse to (1) transformation looks like

$$
x_{i}^{*}=x_{i}^{* \max } \tilde{x}_{i}^{*}-x_{i}^{* \min }\left(\tilde{x}_{i}^{*}-1\right)
$$

in this case, if $x_{i}^{* \min } \leq x_{i}^{*} \leq x_{i}^{* \max }$, then $0 \leq \tilde{x}_{i}^{*} \leq 1$.

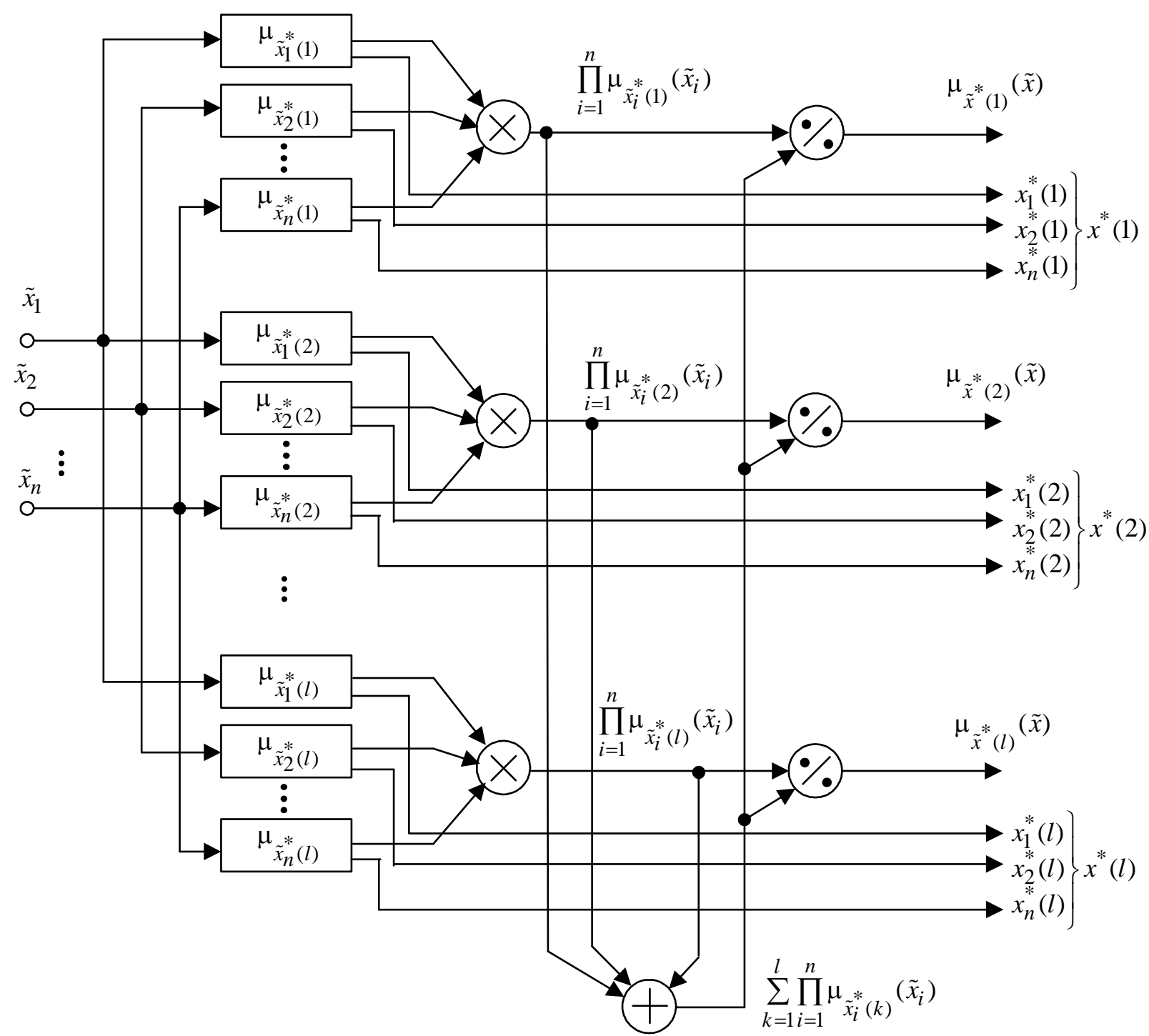

Fig. 1. Recording subsystem of associative memory network using fuzzy basis functions

In the simplest case membership functions can be triangle, as shown in Fig.2, and their analytical expression is

$$
\mu_{l i}\left(\tilde{x}_{i}\right)=\frac{\tilde{x}_{i}-c_{l-1, i}}{1-c_{l-1, i}} \text {, if } \tilde{x}_{i} \in\left[c_{l-1, i}, 1\right] \text {, }
$$

$$
\mu_{1 i}\left(\tilde{x}_{i}\right)=\frac{c_{2 i}-\tilde{x}_{i}}{c_{2 i}} \text {, if } \tilde{x}_{i} \in\left[0, c_{2 i}\right] \text {, }
$$




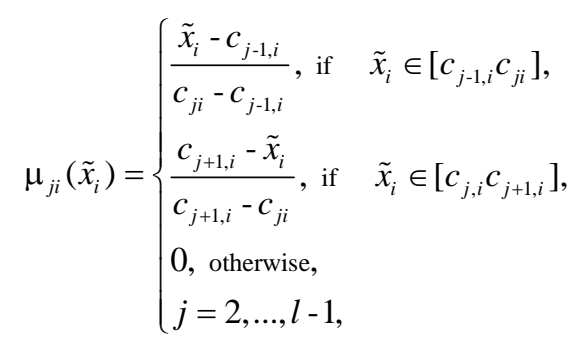

where $c_{j i}$ - parameter of membership function centre, which is defined in learning process.

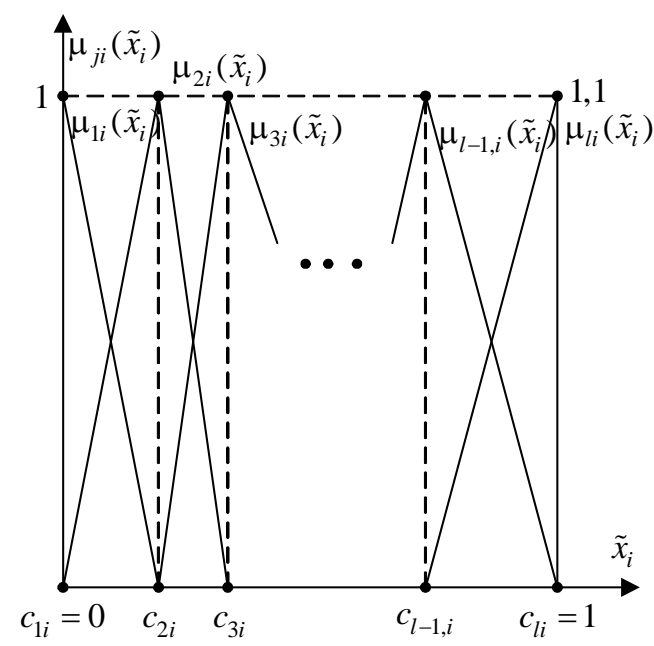

Fig. 2. Membership functions of recording subsystem

Such a way to specify membership functions provides Ruspini unity partition automatically, i.e., the condition

$$
\sum_{j=1}^{l} \mu_{j i}\left(\tilde{x}_{i}\right)=1,
$$

holds, although it is possible to use other functions.

The first layer membership functions are united in $l$ blocks of $n$ functions, and each of the blocks corresponds to one particular pattern of fundamental memory $\tilde{x}^{*}(k)$. The second hidden layer is formed by $l$ multiplication blocks. This layer implements activation values aggregation of each stored pattern so that in multiplication blocks values $\prod_{i=1}^{n} \mu_{\tilde{x}_{i}^{*}(k)}\left(\tilde{x}_{i}\right)$ are computed. After that these values are added in the summation unit of third hidden layer, which computes the value $\sum_{k=1}^{l} \prod_{i=1}^{n} \mu_{\tilde{x}_{*}^{*}(k)}\left(\tilde{x}_{i}\right)$. Output layer realizes the normalization of the output signal so that when the arbitrary $n$-dimensional pattern $\tilde{x}$ feeds to the system input, $l$ signals

$$
\mu_{\tilde{x}^{*}(k)}(\tilde{x})=\frac{\prod_{i=1}^{n} \mu_{\tilde{x}_{i}^{*}(k)}\left(\tilde{x}_{i}\right)}{\sum_{k=1}^{l} \prod_{i=1}^{n} \mu_{\tilde{x}_{i}^{*}(k)}\left(\tilde{x}_{i}\right)}, k=1,2, \ldots, l
$$

appear in the output.

Learning process of the given architecture is similar to the probabilistic neural networks [14] and general regression neural networks [15] learning and is realized by the principle "neurons at data points" [16], so that centres of the membership functions of the first layer coincide with the coordinates of stored patterns projections.

This process is illustrated with an example in Fig.3. In the upper part of Fig.3 three two-dimensional patterns $x^{*}(1), x^{*}(2), x^{*}(3)$ of the fundamental memory to be stored are shown. Their projections onto the axes $x_{1}$ and $x_{2}$ are disposed so that $x_{1}^{*}(1)<x_{1}^{*}(3)<x_{1}^{*}(2)$ and $x_{2}^{*}(3)<x_{2}^{*}(2)<x_{2}^{*}(1)$. These patterns denoted as $\tilde{x}^{*}(1), \tilde{x}^{*}(2), \tilde{x}^{*}(3)$ after the transformation (1) are shown in the lower part of Fig.3. They are placed either in the vertices or on the sides of the unit square (hypercube in the multi-dimensional case). In this specific situation, the architecture shown in Fig.1 has two inputs and six membership functions $\mu_{\tilde{x}_{1}^{*}(1)}, \mu_{\tilde{x}_{2}^{*}(1)}, \mu_{\tilde{x}_{1}^{*}(2)}, \mu_{\tilde{x}_{2}^{*}(2)}, \mu_{\tilde{x}_{1}^{*}(3)}, \mu_{\tilde{x}_{2}^{*}(3)}$. Membership functions centres relate to the projections of the patterns $\tilde{x}^{*}(k)$ onto the axes $\tilde{x}_{i}^{*}(k)$ so that $c_{11}=\tilde{x}_{1}^{*}(1)=0$, $c_{21}=\tilde{x}_{1}^{*}(3), c_{31}=\tilde{x}_{1}^{*}(2)=1$ and $c_{12}=\tilde{x}_{2}^{*}(3)=0, c_{22}=\tilde{x}_{2}^{*}(2)$, $c_{32}=\tilde{x}_{2}^{*}(1)=1$. Each of the centres connects with its own membership function $\mu_{j i}, j=1,2,3 ; i=1,2$, also illustrated in Fig. 3 and described by the relations (2)-(4). Thus, membership functions centres are defined during the learning process in the first layer and unique correspondence between $\tilde{x}_{i}^{*}(k)$ and $c_{j i}$ and between $\mu_{\tilde{x}_{i}^{*}(k)}$ and $\mu_{j i}$ is determined.

Thereby, the membership functions number is changing during the learning process, which allows one to refer the proposed network to the evolving connectionist systems [17].

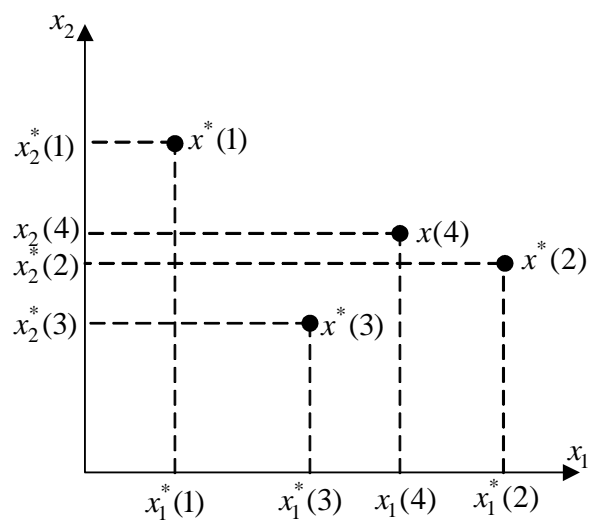

a)

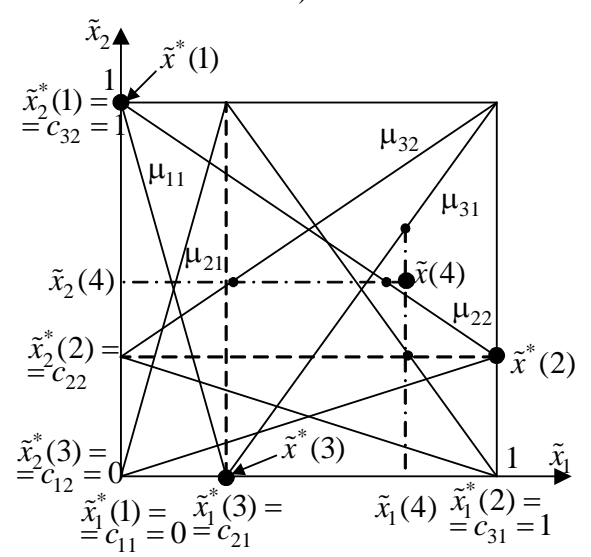

b)

Fig. 3. Learning of the membership functions centres. 
As a result of learning process, the architecture of the associative memory recording subsystem is formed [18]. It is defined by the fundamental memory patterns number. Also membership functions, which are defined by the mutual disposition of the patterns, are calculated.

\section{PATTERN RETRIEVAL FROM THE AUTOASSOCIATIVE MEMORY BASED ON FUZZY BASIS FUNCTIONS}

After the $l$ patterns of the fundamental memory $\tilde{x}^{*}(1), \tilde{x}^{*}(2)$, $\tilde{x}^{*}(l)$ are stored in the autoassociative memory, the system is ready to operate in the retrieval phase. Recording subsystem, shown in Fig.1, must be supplemented by $1(n+1)$-input multiplier units, adder with $n l$ inputs and maximum detector. Patterns $x(p), p=l+1, l+2, \ldots$, which are fed to the system, also must be encoded according to the relation (1). However the situations when $\tilde{x}_{i}(p)$ takes either negative or greater than unity value are possible. As a result, an additional transformation of the input signals must be included

$$
\tilde{x}_{i}(p)=\left\{\begin{array}{l}
0, \text { if } \tilde{x}_{i}(p)<0, \\
\tilde{x}_{i}(p), \text { if } 0 \leq \tilde{x}_{i}(p) \leq 1, \\
1, \text { if } \tilde{x}_{i}(p)>1,
\end{array}\right.
$$

i.e., practically the projection on the unit segment $[0,1]$ is made.
When the arbitrary pattern $\tilde{x}(p)$ is fed to the input of the system, shown in Fig.4, its membership levels to each of the patterns from the fundamental memory are calculated as

$$
\mu_{\tilde{x}^{*}(k)}(\tilde{x}(p))=\frac{\prod_{i=1}^{n} \mu_{\tilde{x}_{i}^{*}(k)}\left(\tilde{x}_{i}(p)\right)}{\sum_{k=1}^{l} \prod_{i=1}^{n} \mu_{\tilde{x}_{i}^{*}(k)}\left(\tilde{x}_{i}(p)\right)}, k=1,2, \ldots, l,
$$

after what, maximum detector defines maximum membership value $\mu_{\tilde{x}^{*}(k)}^{\max }(\tilde{x}(p))$. The output signals of the autoassociative memory are this maximum value and pattern of the fundamental memory $\tilde{x}^{*}(k)=\arg \mu_{\tilde{x}^{*}(k)}^{\max }(\tilde{x}(p))$ corresponding to it.

Once more operating phase is provided in this system. It is assumed that the processed pattern $\tilde{x}(p)$ can be associated not with unique pattern of the fundamental memory $\tilde{x}^{*}(k)$, but can be represented as a combination of the patterns group, with which $\tilde{x}(p)$ connects with nonzero membership. At that, in the output of the system the "hybrid" pattern of the fundamental memory appears

$$
\overline{\tilde{x}}^{*}(\tilde{x}(p))=\sum_{k=1}^{l} \mu_{\tilde{x}^{*}(k)}(\tilde{x}(p)) \tilde{x}^{*}(k) .
$$

Estimate (6) doesn't need additional normalization because of condition (5).

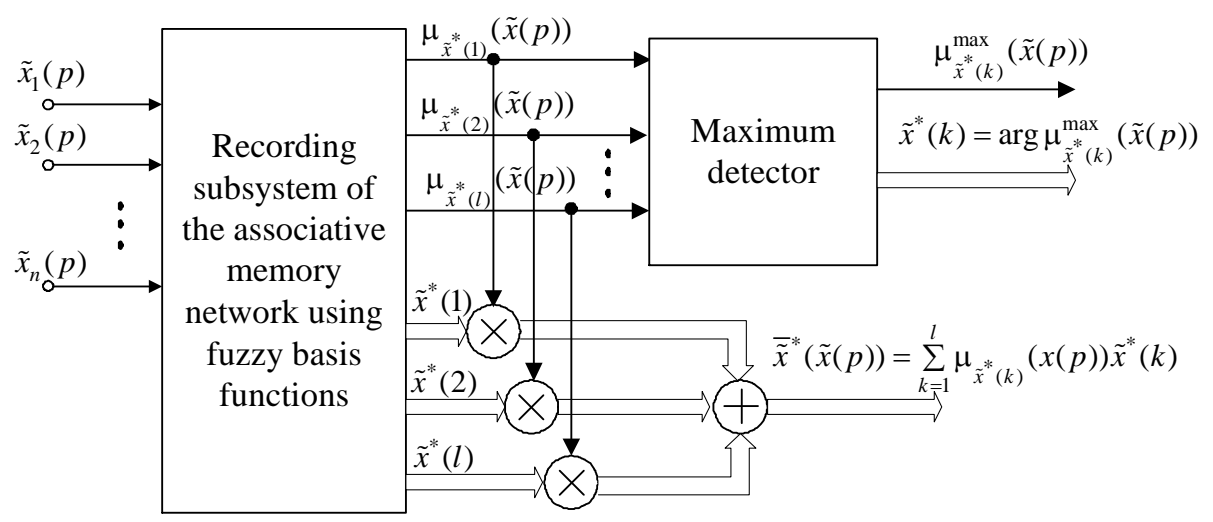

Fig. 4. Patterns retrieval in neural network associative memory based on fuzzy basis functions

Retrieval process can also be illustrated using Fig. 3, where the pattern, fed to the system after its learning is denoted as $x(4)$ in Fig. 3a and as $\tilde{x}(4)$ in Fig. 3b. It is easy to see that $x(4)$ is connected with $\tilde{x}^{*}(2)$ by maximum membership level, and $\tilde{x}^{*}(2)$ will be chosen by the maximum detector.

Fundamental memory patterns $\tilde{x}^{*}(1), \tilde{x}^{*}(2), \tilde{x}^{*}(3)$ attraction regions (hatched) are shown in Fig. 5. It is clear that pattern $\tilde{x}(4)$ belongs only to the attraction region of the $\tilde{x}^{*}(2)$, which leads to the fact that signal $\overline{\tilde{x}}^{*}(\tilde{x}(4))$ will equal to $\tilde{x}^{*}(2)$. At the same time pattern $\tilde{x}(5)$, also depicted on the fig.5, belongs to the attraction regions of the $\tilde{x}^{*}(2)$ and $\tilde{x}^{*}(3)$ simultaneously, i.e., a "hybrid" pattern will appear in the output of the system

$$
\overline{\tilde{x}}^{*}(\tilde{x}(5))=\mu_{\tilde{x}^{*}(2)}(\tilde{x}(5)) \tilde{x}^{*}(2)+\mu_{\tilde{x}^{*}(3)}(\tilde{x}(5)) \tilde{x}^{*}(3) .
$$

However, when the fundamental memory capacity $l$ is large, attraction regions of each pattern $\tilde{x}^{*}(k)$ can be very small, which leads to the appearance of "gaps" in pattern space $R^{n}$. Returning to the architecture, shown in Fig.1, this means that in the output of the second hidden layer zeros arise as a result of membership functions aggregation, which means that neural network memory cannot retrieve pattern presented to it.

In this case the computation of distances between $\tilde{x}(p)$ and all patterns of the fundamental memory $\tilde{x}^{*}(k)$

$$
d\left(\tilde{x}(p), \tilde{x}^{*}(k)\right)=\left\|\tilde{x}(p)-\tilde{x}^{*}(k)\right\|, k=1,2, \ldots, l,
$$

is made. 


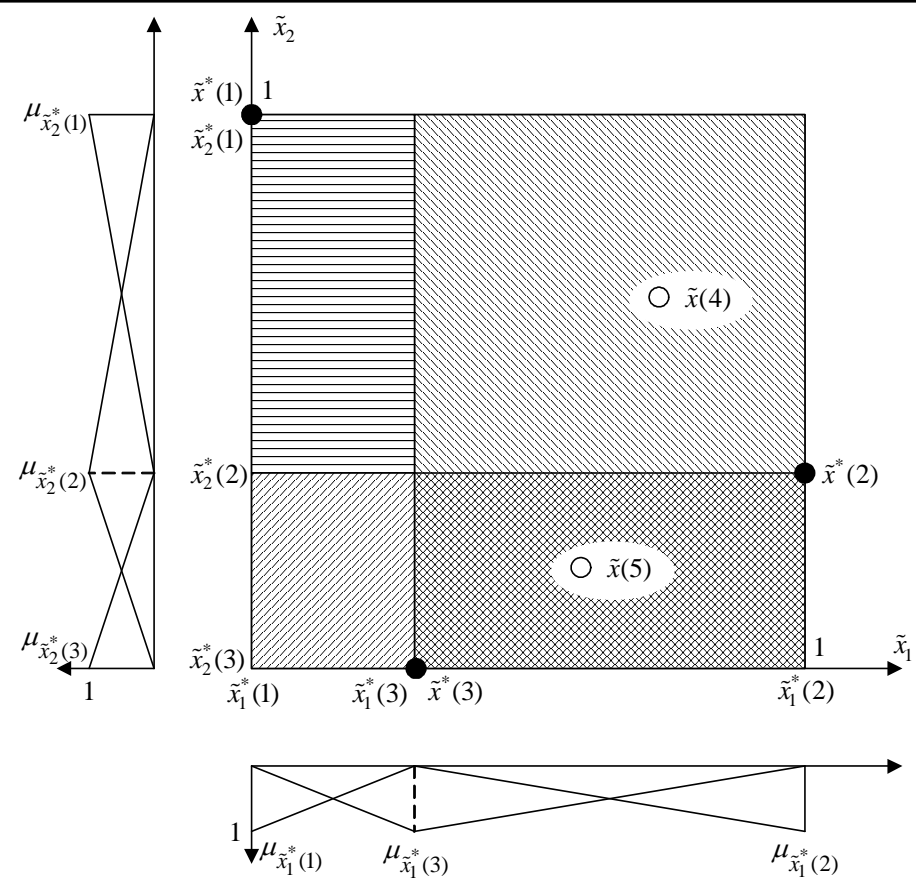

Fig. 5. Attraction regions of the autoassociative memory based on fuzzy basis functions

The least two distances $d_{\text {min min }}\left(\tilde{x}(p), \tilde{x}^{*}(k)\right), d_{\text {min }}\left(\tilde{x}(p), \tilde{x}^{*}(k)\right)$ are chosen, after what membership levels are computed according to the expressions [19]

$$
\begin{aligned}
& \mu^{\max \max }(\tilde{x}(p))=\frac{d_{\text {min min }}^{-2}\left(\tilde{x}(p), \tilde{x}^{*}(k)\right)}{d_{\text {min min }}^{-2}\left(\tilde{x}(p), \tilde{x}^{*}(k)\right)+d_{\text {min }}^{-2}\left(\tilde{x}(p), \tilde{x}^{*}(k)\right)}, \\
& \mu^{\max \max }(\tilde{x}(p))=\frac{d_{\text {min }}^{-2}\left(\tilde{x}(p), \tilde{x}^{*}(k)\right)}{d_{\text {min min }}^{-2}\left(\tilde{x}(p), \tilde{x}^{*}(k)\right)+d_{\text {min }}^{-2}\left(\tilde{x}(p), \tilde{x}^{*}(k)\right)} .
\end{aligned}
$$

Then in the output of autoassociative memory the "hybrid" signal appears as a result of retrieval

$$
\overline{\tilde{x}}^{*}(\tilde{x}(p))=\mu^{\max \max }(\tilde{x}(p)) \tilde{x}_{\min \min }^{*}(k)+\mu^{\max }(\tilde{x}(p)) \tilde{x}_{\min }^{*}(k),
$$

where $\tilde{x}_{\text {min min }}^{*}(k), \tilde{x}_{\text {min }}^{*}(k)$ are fundamental memory patterns the nearest to the $\tilde{x}(p)$.

\section{IV.EXPERIMENTAL RESULTS}

For autoassociative memory based on fuzzy basis functions simulation the sample Pima Indians Diabets [20] was used. It presents pima tribe indians diabet index and contains 768 patterns and 8 features. For comparison of operation efficiency of autoassociative memory based on fuzzy basis functions the correlation matrix memory was used [21]. The experiment was carried out under different initial conditions 100 times, the results were averaged.

Correlation matrix memory is characterized by the ability to memorize patterns exclusively less than the number of data features, in our case not more than 7. The retrieval accuracy by such memory volume is $33 \%$. If the fundamental memory of correlation matrix-memory capacity is increased, then weight coefficients matrix tends to identity matrix, therefore presented patterns couldn't be correctly retrieved.

In Table I the results of patterns retrieval using autoassociative memory based on fuzzy basis functions with different fundamental memory volumes are summarised.

From Table I one can draw the conclusion that autoassociative memory based on fuzzy basis functions as opposed to correlation matrix memory is able to memorize arbitrary number of patterns and retrieval accuracy increases when the fundamental memory capacity is extended.

TABLE I

THE RESULTS OF AUTOASSOCIATIVE MEMORY BASED ON FUZZY BASIS FUNCTIONS OPERATION

\begin{tabular}{|l|l|}
\hline Memory volume & Memory volume \\
\hline 5 & $43 \%$ \\
\hline 10 & $51 \%$ \\
\hline 50 & $62 \%$ \\
\hline 100 & $71 \%$ \\
\hline 200 & $76 \%$ \\
\hline 300 & $85 \%$ \\
\hline 400 & $91 \%$ \\
\hline 500 & $94 \%$ \\
\hline 600 & $97 \%$ \\
\hline
\end{tabular}

\section{CONCLUSIONS}

The architecture and learning algorithms of autoassociative neural network memory based on fuzzy basis functions are proposed. This memory has increased capacity and is characterized by simplicity of the realization. The proposed neuro-fuzzy associative memory has expanded functional 
possibilities and allows making the retrieval in the form of fundamental memory patterns weighted combination.

\section{REFERENCES}

[1] Specht, D.F. Probabilistic neural networks for classification, mapping, or associative memory. Proc. IEEE Int. Conf. Neural Networks.V.1, 1988, pp. 525-432.

[2] Michel, A.N., Farrel, J.A. Associative memories via artificial neural networks. IEEE Control System Magazine.10(3), 1990, pp. 6-17.

[3] Hassoun, M.H. Fundamentals of Artificial Neural Networks. Cambridge, MA: MIT Press, 1995.

[4] Rojas, R. Neural Networks. A Systematic Introduction. Berlin: SpringerVerlag, 1996.

[5] Hagan, M.T., Demuth, H.B., Beale, M. Neural Networks Design. Boston: PWS Publishing Company, 1996.

[6] Hassoun, M.H., Watta P.B. Associative memory networks. In "Handbook of Neural Computation". Oxford: IOP Publishing Ltd. and Oxford University Press, 1997.

[7] Haykin, S. Neural Networks. A Comprehensive Foundation. New York: Prentice Hall, Inc., 1999.

[8] Brown, M., Harris, C.J. Neural networks for modeling and control. In Eds. by C.J. Harris “Advances in Intellectual Control”. London: Taylor and Francis, 1994

[9] Wang, H., Liu, G.P., Harris, G.J., Brown, M. Advanced Adaptive Control. Oxford: Pergamon, 1995.

[10] Wang, L.-X., Mendel, J.M. Fuzzy basis functions, universal approximation, and orthogonal least squares learning. IEEE Trans. on Neural Networks.3, 1992, pp.807-814.

[11] Jang, J.-S. R., Sun, G.-T. Neuro-fuzzy modeling and control. Proc. IEEE.83, 1995, pp. 378-406

[12] Cios, K.J., Pedrycz, W. Neuro-fuzzy algorithms. In "Handbook on Neural Computation". Oxford: IOP Publishing Ltd and Oxford University Press, 1997.

[13] Wang, L.X. Adaptive Fuzzy Systems and Control. Design and Stability Analysis. New York: Prentice Hall, 1994.

[14] Specht, D.F. Probabilistic neural networks. Neural Networks.3, 1990, pp.109-118.

[15] Specht, D.F. A general regression neural network. IEEE Trans. on Neural Networks. 2, 1991, pp. 568-576.

[16] Zahirniak, D.R., Chapman, R., Rogers, S.K., Suter, B.W., Kabrisky, M., Pyati, V. Pattern recognition using radial basis function network. Proc. 6-th Ann. Aerospace Application of AI Conf. Dayton, 1990, pp. 249-260.

[17] Kasabov, N. Evolving Connectionist Systems: Methods and Applications in Bioinformatics. Brain Study and Intelligent Machines. London: Springer-Verlag, 2002
[18] Bodyanskiy, Ye., Teslenko, N. Autoassociative neural memory on the basis of fuzzy basis functions. Bionics of Intelligence. 1(66), 2007, 5357. (in Russian)

[19] Bezdek, J.C. Pattern Recognition with Fuzzy Objective Algorithms. New York: Plenum Press, 1981.

[20] Murphy P. M., Aha, D. UCI Repository of machine learning databases. [Online]. http://www.ics.uci.edu/ mlearn/MLRepository.html.

[21] Bodyanskiy, Ye., Rudenko, O. Artificial neural networks: architecture, learning, application. Kharkov: TELETECH, 2004.

Yevgeniy Bodyanskiy. In 1971 graduated with honour Kharkiv National University of Radio Electronics. In 1980 has defended the candidate thesis. In 1984 has taken academic title Senior Researcher. In 1990 defended the doctor thesis (Dr.habil.sci.ing.). In 1994 has taken academic title Professor. His major field of research is technical cybernetics and information theory, control in technical systems.

Since 1974 he has been working at Kharkiv National University of Radio Electronics. In 1974-1976 researcher, 1977-1983 senior researcher, 1983-1991 head of group of Control Systems Research Laboratory, 1991-1992 fellow researcher, since 1992 professor of Artificial Intelligence Department KhNURE, scientific head of Control Systems Research Laboratory KhNURE. He has more than 500 scientific publications including 40 inventions and 10 monographs. Research interests include hybrid systems of computational intelligence: adaptive, neuro-, wavelet-, neo-fuzzy-, real-time systems including problems connected with control, identification, forecasting, clustering, diagnostics, fault detection in technical, economical, medical and ecological objects.

Senior member of IEEE, member of 4 scientific and 7 editorial boards.

Contact data: Office 511, Lenin Av., 14, Kharkiv, 61166, Ukraine.

E-mail: bodya@kture.kharkov.ua.

Nataliya Teslenko. In 2003 graduated from Kharkiv National University of Radio Electronics by speciality "Intellectual Systems of Decisions Making", 2005-2009 postgraduate study in Artificial Intelligence Department, has defended the candidate thesis in 2009 (Dr.sc.ing.). Her major field of research is self-learning evolving neuro-fuzzy models and systems in the intelligent data analysis tasks.

After post-graduate study works in Control Systems Research Laboratory at Kharkiv National University of Radio Electronics. Has more than 30 publications. Research interests are neuro-fuzzy systems for information compression, principal component analysis, clusterization, autoassociative memory, kernel systems and evolving systems.

Contact data: Office 511, Lenin Av., 14, Kharkiv, 61166, Ukraine. E-mail: ntntp@ukr.net.

\section{Jevgeṇijs Bodjanskis, Natālija Teslenko. Uz izplūdušām bāzes funkcijām balstīta autoasociatīvās atmiṇas evolucionējoša sistēma}

Rakstā piedāvāta evolucionējošas autoasociatīvas atminas neironu-izplūduma arhitektūra. Dotās konstrukcijas apmācības algoritms balstīts uz izplūdušu bāzes funkciju izmantošanu. Piedāvāts bāzes funkciju jeb piederības funkciju centru noteikšanas algoritms, kā arī izskatīti fundamentālās atminas tēlu uzkrāšanas un to turpmākas atjaunošanas procesi. Apskatītās arhitektūras apmācības process tiek realizēts pēc principa „neironi datu punktos” tādā veidā, lai piederības funkciju centri sakristu ar iegaumējamo tēlu projekciju koordinātām. Piedāvātā hibrīdā evolucionējošā neironu-izplūduma sistēma ietver mākslīgo neironu tîklu, izplūdušā izveduma sistēmu un evolucionējošo sistēmu priekšrocības, un tās izmantošana l̦auj paaugstināt autoasociatīvās atmiņas lielumu, nesarežğījot tās konstrukciju. Ieviestajai evolucionējošās neironu-izplūduma asociatīvās atmiņas sistēmai piemīt plašas funkcionālās iespējas, un tā l̦auj realizēt atjaunošanu svērtā fundamentālās atminas tēlu kombināciju formā.

Евгений Бодянский, Наталия Тесленко. Эволюционирующая система автоассоциативной памяти на основе нечётких базисных функций В статье предложена нейро-фаззи архитектура эволюционирующей автоассоциативной памяти. Алгоритм обучения данной конструкции основан на использовании нечетких базисных функций. Представлен алгоритм определения центров базисных функций или функций принадлежности, а также рассмотрены процессы накопления образов фундаментальной памяти и их последующего восстановления. Процесс обучения данной архитектуры реализуется по принципу «нейроны в точках данных» так, что центры функций принадлежности совпадают с координатами проекций запоминаемых образов. Предложенная гибридная эволюционирующая нейро-фаззи система сочетает в себе преимущества искусственных нейронных сетей, систем нечеткого вывода, и эволюционирующих систем, а её использование позволяет повысить емкость автоассоциативной памяти без существенного усложнения конструкции. Введенная система эволюционирующей нейро-фаззи ассоциативной памяти обладает расширенными функциональными возможностями и позволяет производить восстановление в форме взвешенной комбинации образов фундаментальной памяти. 